\title{
Pengaruh Penggunaan Mulsa Jerami Pada Sistem Tumpang Sari Tanaman Jagung Manis (Zea Mays saccharata Sturt) dan Kacang Kedelai (Glycine max (L) Merill) Terhadap Pertumbuhan dan Produksi
}

\section{Influence of Straw Mulch Plants In intercropping system Sweet Corn (Zea Mays saccharata Sturt) and Soybean (Glycine max (L) Merrill) on Growth and Production}

\section{Tutik Nugrahini}

Program Studi Agroteknologi, Fakultas Pertanian, Universitas Widya Gama Mahakam Jl. KH. Wahid Hasyim, Sempaja, Samarinda, Kalimantan Timur, Indonesia Telp : (0541) 734294-737222, Fax : (0541) 736572

email : tutik_nugrahini@yahoo.com

Diterima : 14 Juni 2012 Disetujui : 7 September 2012

\section{ABSTRACT}

Influence of Straw Mulch on intercropping system Crop Sweet Corn (Zea mays saccharata Sturt) and Soybean (Glycine $\max (L)$ Merrill) on Growth and Production. The aim of research to determine the effect of mulching straw on intercropped plants sweet corn (Zea mays saccharata Sturt.) And soybean (Glycine max (L) Merrill) on the growth and production. Research dilakanakan for 4 months starting from May to August of 2010, starting from land preparation to harvest. Location of research carried out in the village of Muara Bengkal ngayau East Kutai. This study was conducted using the Draft Plots Separated (RPT) with analysis of $2 \times 5$ and each -masing treatment was repeated 4 times. As the main plot (main plot) is a straw mulch consisting of two levels, namely: mo = without straw mulch, $m 1=$ with straw mulch. Meanwhile, as the subplots (sub plot) is the use of intercropping systems $(P)$ consists of 5 levels:: $p 1=$ soybean monoculture, $p 2=$ sweet corn monoculture, $p 3=$ intercropping soybean + maize dibarisan middle, $p 4=$ intercropping 3 lines corn among soybean, $p 5=$ intercropping two rows of corn beside the left and right of the soybean crop. The results showed a significant effect of straw mulching treatment. Treatment cropping system significantly. Combination treatment with straw mulching intercropping system had no significant effect.

Keywords: straw mulch, intercropping sweet corn and soybeans.

\section{ABSTRAK}

Pengaruh Penggunaan Mulsa Jerami pada Sistem Tumpang Sari Tanaman Jagung Manis (Zea mays saccharata Sturt) dan Kacang Kedelai (Glycine max (L) Merill) Terhadap Pertumbuhan dan Produksi. Tujuan penelitian untuk mengetahui pengaruh penggunaan mulsa jerami pada tumpangsari tanaman jagung manis (Zea mays saccharata Sturt.) dan kacang kedelai (Glycine $\max (\mathrm{L})$ Merill ) terhadap pertumbuhan dan produksi. Penelitian dilakanakan selama 4 bulan dimulai sejak bulan Mei sampai dengan bulan Agustus 2010, terhitung sejak persiapan lahan hingga panen. Lokasi penelitian dilaksanakan di Desa Ngayau Kecamatan Muara Bengkal Kabupaten Kutai Timur. Penelitian ini dilaksanakan dengan menggunakan Rancangan Petak Terpisah (RPT) dengan analisis 2 x 5 dan masing -masing perlakuan diulang 4 kali. Sebagai petak utama (main plot) adalah mulsa jerami yang terdiri dari 2 taraf, yaitu : $m o=$ tanpa mulsa jerami, $\mathrm{m}_{1}=$ dengan mulsa jerami. Sedangkan sebagai anak petak (sub plot) adalah penggunaan sistem tumpang sari $(\mathrm{P})$ terdiri dari 5 taraf, yaitu : $\mathrm{p}_{1}=$ kedelai monokultur, $\mathrm{p}_{2}=$ jagung manis monokultur, $\mathrm{p}_{3}=$ tumpang sari kedelai + jagung dibarisan tengah, $\mathrm{p}_{4}=$ tumpang sari 3 baris jagung di antara tanaman kedelai, $\mathrm{p}_{5}=$ tumpang sari 2 baris jagung disamping kiri dan kanan tanaman kedelai. Hasil penelitian menunjukkan perlakuan mulsa jerami berpengaruh nyata. Perlakuan sistem tumpangsari berpengaruh nyata. Kombinasi perlakuan mulsa jerami dengan sistem tumpangsari tidak berpengaruh nyata.

Kata kunci : Mulsa jerami, tumpang sari jagung manis dan kedelai.

\section{PENDAHULUAN}

Sebagai salah satu negara agraris, dimana sebagian besar penduduk hidup disektor pertanian. Indonesia mempunyai potensi yang cukup besar untuk meningkatkan taraf hidup dan pemasukan devisa negara dari sektor pertanian untuk mencapai kesejahteraan dan kemakmuran bangsa. Kalimantan merupakan daerah yang mempunyai potensi cukup bagi pertumbuhan dan pengembangan tanaman pangan dengan curah hujan yang berkisar $1500-4500 \mathrm{~mm} /$ tahun, sehingga dapat mencukupi kebutuhan air bagi tanaman, juga masih luasnya lahan yang berpotensi untuk tanaman pangan seperti kedelai
(BPTP Kaltim, 1999). Kedelai merupakan sumber protein yang besar artinya untuk kesehatan dan perkembangan tubuh manusia, terutama akan terasa sekali bagi masyarakat yang konsumsi protein hewaninya masih rendah. Menurut Rismunandar (1983), kedelai sabagai sumber protein nabati bijinya mengandung protein $40 \%$, lemak $20 \%$ dan karbohidrat $17 \%$. Kedelai dapat digunakan untuk berbagai macam keperluan, untuk makanan manusia, makanan ternak dan untuk bahan industri, contohnya industri minyak nabati. Di Indonesia penggunaan kedelai masih terbatas sebagai bahan makanan manusia dan ternak. Makanan yang terbuat dari kedelai antara lain adalah kedelai rebus, kedelai 
goreng, kecambah, tempe, tahu, tauco dan kecap (Suprapto, 1998). Konsumsi kedelai secara nasional memang meningkat tajam. Sebagai gambaran pada tahun 1998 ini diproyeksikan kebutuhan kedelai nasional mencapai lebih dari 2,3 juta ton biji kering, tahun 2003 sekitar 2,8 juta ton biji kering dan tahun 2010 naik menjadi 3,9 juta ton biji kering. Permintaan tersebut untuk memenuhi kebutuhan industri pengolahan pangan dan industri pakan ternak (Utami, 1998). Rata rata produksi kedelai secara nasional yang mencapai 1,06 ton $\mathrm{ha}^{-1}$ dan potensi hasil varietas unggul yang dapat mencapai 1,50 - 1,70 ton $\mathrm{ha}^{-1}$

\section{(Dispertan Kaltim, 2000).}

Rendahnya produksi kedelai di Kalimantan Timur kemungkinan disebabkan karena belum meluasnya areal penanaman dan kurangnya perhatian petani akan teknik budidaya kedelai yang baik diantaranya pengolahan tanah dan pemupukan. Ditambahkan oleh Utami (1998), beberapa kendala dalam peningkatan produksi kedelai diantaranya waktu tanam yang belum tepat, cekaman kekeringan, gangguan hama dan penyakit, pemupukan yang rendah, teknik budidaya dan tingkat kesuburan tanah yang rendah. Selain itu ada beberapa faktor yang menyebabkan rendahnya produksi kedelai di Indonesia adalah cara bercocok tanam, pemeliharaan kurang intensif, mutu benih rendah, petani belum sepenuhnya menerapkan paket teknologi pertanian yang dianjurkan dan faktor iklim serta tingkat kesuburan tanah yang relatif rendah (AAK, 1989). Untuk meningkatkan kesuburan tanah, dapat dilakukan dengan penambahan unsur hara yang diperlukan dengan jalan pemupukan, misalnya dengan pupuk organik. Pemberian pupuk organik dapat diterapkan dengan cara pemberian kompos, yang mudah lapuk dan membusuk, sehingga mudah dan siap diserap oleh tanaman. Kompos adalah bahan organik yang terdiri dari daun-daunan, ranting, atau batang yang mudah membusuk di dalam tanah (AAK, 1988). Sutedjo dan Kartasapoetra (1988) menambahkan bahwa kadar mineral dari bahan organik (kompos) memang rendah sehingga masih memerlukan pelapukan terlebih dahulu sebelum diserap oleh tanaman. Namun bermanfaat cukup besar untuk kesuburan tanah. Di udara terdapat kurang lebih $80 \%$ nitrogen $\left(\mathrm{N}_{2}\right)$ dalam keadaan bebas. Mengingat pentingnya nitrogen bagi pertumbuhan tanaman maka patutlah dipikirkan bagaimana memanfaatkannya. Cara yang paling praktis, ekonomis dan efektif untuk memanfaatkan nitrogen bebas di udara untuk meningkatkatkan produksi kacang-kacangan adalah dengan mencampurkan biakan bakteri Rhizobium dengan benih kacang-kacangan sebelum ditanam dikenal dengan istilah inokulasi. Kerja sama antara bakteri Rhizobium dengan tanaman kacang-kacangan akan berjalan baik apabila kondisi tanah dan iklimnya dalam keadaan baik pula. Di Indonesia tanaman jagung (Zea mays L) merupakan komoditas pangan kedua setelah beras, yang kaya akan kadar karbohidrat bahkan beberapa daerah dijadikan makanan pokok yang setara dengan beras. Jagung manis $(Z$. saccharata) merupakan komoditas yang sudah dikenal masyarakat dan memegang peranan yang sangat penting dalam memenuhi kebutuhan pangan di Indonesia untuk memenuhi kebutuhan karbohidrat pengganti beras (Suprapto, 1997).

Komoditas jagung manis ini mempunyai keuntungan yang sangat besar untuk dikembangkan karena dapat diusahakan sepanjang tahun, umur produksi lebih pendek (genjah) dan harga cukup tinggi. Melihat perkembangan kebutuhan yang jauh diatas kemampuan produksi dalam negeri maka upaya peningkatan produksi jagung tidak dapat di tawar - tawar lagi. Upaya ini sebenarnya sudah lama dirintis dengan berbagai program oleh pemerintah, diantaranya ialah Insus (Intensifikasi khusus) yang berlanjut ke Supra Insus yang bertujuan agar swasembada jagung dapat tercapai. Bila target produksi tersebut dapat dicapai maka akan ada kelebihan produksi untuk ekspor. Thailand dan Malaysia merupakan dua negara tujuan ekspor jagung tersebut.

Hal lain yang mendorong petani menanam jagung adalah jaminan harga yang cukup baik. Melemahnya rupiah terhadap dollar Amerika Serikat menyebabkan harga jagung impor relatif mahal dibanding harga jagung dalam negeri. Akibatnya, produksi jagung dalam negeri akan terserap pasar.

Secara ekonomi tanaman jagung ini mempnyai peranan penting bagi kehidupan manusia. Hal ini karena tanaman jagung selain digunakan sebagai bahan pangan juga dapat digunakan bahan baku industri dan makanan ternak. Usaha peningkatan produksi jagung secara besar dapat diperoleh dari perluasan areal tanaman (Ekstensifikasi) dan peningkatan produksi persatuan luas (Intensifikasi), peningkatan produksi ini dapat dicapai melalui pemakaian bibit unggul. Pemupukan yang tepat memperbaiki pengelolaan usaha tani, termasuk pengendalian hama dan penyakit. Mengingat tanah di Kalimantan Timur tingkat kesuburannya rendah, sehingga perlu untuk meningkatkan produksi tanaman jagung adalah melalui pemupukan (Dispertan Kaltim, 1998). Meningkatkan produksi tanaman tidak lepas dari pengaruh penyerapan unsur hara dalam tanah. Melengkapi unsur hara dalam tanah dan mencukupi kebutuhan unsur hara dari tanaman yang diusahakan maka berwujudlah pupuk buatan. Pupuk buatan ini biasanya memiliki kandungan hara yang diperlukan dalam jumlah yang besar. Unsur yang diperlukan tanaman jagung seperti nitrogen sekitar150-200 kg urea/ha, pupuk fosfat $75 \mathrm{~kg}$ SP-36/ha dan pupuk kalium sekitar $50 \mathrm{~kg}$ $\mathrm{KCI} / \mathrm{ha}$, dan memiliki kadar seperti urea dengan 
kadar N 45\%, SP-36 dengan kadar $\mathrm{P}_{2} \mathrm{O}_{5} 46 \%$ dan KCL dengan kadar $\mathrm{K}_{2} \mathrm{O} 50 \%$ (PSK SP Kaltim, 1997). Selain pemberian pupuk organik, mulsa memiliki manfaat yang lebih dalam hal kompetisi dengan tanaman pengganggu atau gulma untuk memperoleh sinar matahari. Agar dapat berkecambah, benih gulma membutuhkan sinar matahari. Dengan adanya bahan mulsa diatas permukaan tanah, benih gulma tidak mendapatkan sinar matahari. Kalaupun ada sinar matahari,

\section{BAHAN DAN METODE}

Penelitian dilakanakan selama 4 bulan dimulai sejak bulan April sampai dengan bulan Agustus 2010, terhitung sejak persiapan lahan hingga panen. Lokasi penelitian dilaksanakan di Desa Ngayau Kecamatan Muara Bengkal Kabupaten Kutai Timur Provinsi Kalimatan Timur. Bahan yang digunakan dalam penelitian ini adalah benih kedelai varietas Willis, jagung manis dan mulsa jerami.alat yang digunakan adalah cangkul, parang, lingga, tali rafia, meteran, pisau, alat tugal, timbangan, jangka sorong dan alat tulis menulis. Penelitian ini dilaksanakan dengan menggunakan Rancangan Petak Terpisah (RPT) yang disusun dalam Rancangan Acak Kelompok (RAK) dengan analisis 2 x 5 dan masing -masing perlakuan diulang 4 kali. Sebagai petak utama (main plot) adalah mulsa jerami yang terdiri dari 2 taraf, yaitu : $\mathrm{mo}=$ tanpa mulsa jerami, $\mathrm{m}_{1}=$ dengan mulsa jerami. Sedangkan sebagai anak petak (sub plot) adalah penggunaan sistem mialnya pada mulsa jerami atau plastik transparan, pertumbuhan gulma akan sangat terhalang. Akibatnya tanaman yang ditanam akan bebas tumbuh tanpa kompetisi dengan gulma dalam penyerapan hara mineral tanah. Ketiadaan kompetisi dengan gulma tersebut merupakan salah satu penyebab adanya keuntungan berikutnya yang diharapkan, yaitu meningkatkan produksi tanaman budi daya.

tumpang sari $(\mathrm{P})$ terdiri dari 5 taraf, yaitu : $\mathrm{p}_{1}=$ kedelai monokultur, $\mathrm{p}_{2}=$ jagung manis monokultur, $\mathrm{p}_{3}=$ tumpang sari kedelai + jagung dibarisan tengah, $\mathrm{p}_{4}=$ tumpang sari 3 baris jagung di antara tanaman kedelai, $\mathrm{p}_{5}=$ tumpang sari 2 baris jagung disamping kiri dan kanan tanaman kedelai. Pengambilan data meliputi data ; tinggi tanaman jagung, umur saat berbunga jantan $80 \%$, panjang tongkol, diameter tongkol tanpa kelobot, produksi jagung per petak, tinggi tanaman kedelai, jumlah polong isi per tanaman, jumlah polong hampa per tanaman, berat 100 biji per tanaman dan produksi kedelai per petak Untuk mengetahui pengaruh penggunaan mulsa jerami pada sistem tumpang sari tanaman jagung manis dan kedelai terhadap pertumbuhan dan poduksi maka data dianalisis dengan menggunakan sidik ragam. Bila terdapat pengaruh pada perlakuan maka dilakukan uji lanjutan dengan uji BNT (Beda Nyata Terkecil) pada taraf $5 \%$ untuk membandingkan dua rata-rata perlakuan.

\section{HASIL DAN PEMBAHASAN}

\section{Pengaruh Perlakuan Mulsa Jerami Terhadap Pertumbuhan dan Produksi Tanaman Tumpangsari Jagung Manis dan Kedelai}

\section{Pertumbuhan dan produksi tanaman Jagung Manis}

Tabel 1. Rata-Rata umur saat berbunga jantan $80 \%$ pada Perlakuan Mulsa Jerami

\begin{tabular}{cc}
\hline Perlakuan & Rata-rata umur saat berbunga jantan $80 \%$ (HST) \\
Mulsa Jerami & $47,06^{\mathrm{a}}$ \\
\hline $\mathrm{m}_{0}$ & $48,13^{\mathrm{b}}$ \\
\hline
\end{tabular}

Keterangan : Angka-angka yang diikuti huruf yang sama menunjukkan tidak berbeda nyata berdasarkan uji BNT pada taraf $\alpha=5 \%$

Hasil sidik ragam menunjukan bahwa perlakuan mulsa jerami tidak berpengaruh nyata terhadap tinggi tanaman jagung umur 15, 30 dan 45 HST, panjang tongkol, diameter tongkol tanpa kelobot dan produksi jagung per petak namun berpengaruh nyata terhadap umur saat berbunga jantan $80 \%$. Perlakuan mulsa jerami tidak berpengaruh nyata terhadap tinggi tanaman jagung umur 15, 30 dan 45 HST, panjang tongkol, diameter tongkol tanpa kelobot dan produksi jagung per petak diduga karena jerami yang digunakan sebagai mulsa belum terdekomposisi secara sempurna sehingga unsur hara yang terbentuk dari hasil penguraian bahan organik berupa jerami tersebut belum dapat dimanfaatkan tanaman untuk mencukupi kebutuhan unsur hara bagi pertumbuhan dan produksi tanaman jagung. Menurut Harjadi (1993), banyaknya bahan organik yang terdekomposisi akan mempengaruhi jumlah unsur-unsur mineral yang diperlukan 
untuk pertumbuhan tanaman. Kemudian diperjelas oleh Sutejo (1991), bahwa pertumbuhan tanaman akan berlangsung baik apabila kadar unsur hara yang terkandung dalam tanah tempat tumbuhnya masih baik. Demikian pula menurut Sarief (1986), kesuburan tanah merupakan faktor terpenting untuk menghasilkan produksi pertanian yang optimal tanpa mengurangi tingkat kesuburan tanahnya. Ketersedian unsur hara yang dapat diserap oleh tanaman merupakan faktor untuk mempengaruhi tingkat produksi tanaman.

Perlakuan mulsa jerami berpengaruh nyata terhadap umur saat berbunga jantan $80 \%$ tanaman jagung. Hasil pengamatan diperoleh bahwa tanpa pemakaian mulsa $\left(\mathrm{m}_{0}\right)$ lebih baik daripada dengan pemakaian mulsa $\left(\mathrm{m}_{1}\right)$ dilihat dari umur saat berbunga jantan 80. Hasil uji BNT diperoleh bahwa perlakuan $m_{0}$ (tanpa mulsa jerami) menunjukkan hasil yang lebih baik dibandingkan dengan pemberian mulsa karena tanpa pemberian mulsa umur saat berbunga jantan $80 \%$ lebih cepat yaitu 47,06 hari setelah tanam dibandingkan dengan pemberian mulsa yaitu 48,13 hari setelah tanam. Hal ini diduga karena perlakuan mulsa jerami dapat menurunkan suhu tanah sehingga berpengaruh terhadap penurunan evapotranspirasi yang menyebabkan suhu tanah menurun sehingga memperlambat laju proses fisiologis tanaman. Hal ini sesuai dengan pendapat BIP Sulsel (1994) yang menyatakan bahwa jagung manis menghendaki udara yang cukup panas bagi pertumbuhannya. Terutama sekali pada fase pembungaan dan fase pemasakan buah. Tanaman ini membutuhkan panas dan lembab dari waktu tanam sampai periode pembuahan. Berdasarkan uraian tersebut maka perlakuan $\mathrm{m}_{0}$ (tanpa mulsa jerami) menunjukkan hasil yang terbaik karena tanpa mulsa jerami akan meningkatkan proses fisiologis tanaman melalui peningkatan suhu tanah yang optimal bagi tanaman jagung sebagai syarat tumbuhnya sehingga akan mempercepat umur saat berbunga jantan $80 \%$.

\section{Pertumbuhan dan produksi tanaman kedelai}

Tabel 2. Rata-Rata Tinggi Tanaman Kedelai pada Perlakuan Mulsa Jerami

\begin{tabular}{cccc}
\hline Perlakuan & \multicolumn{3}{c}{ Rata-rata tinggi tanaman kedelai (cm) } \\
\cline { 2 - 4 } Mulsa Jerami & $15 \mathrm{HST}$ & $30 \mathrm{HST}$ & $45 \mathrm{HST}$ \\
\hline $\mathrm{m}_{0}$ & 18,44 & 30,63 & $45,18^{\mathrm{b}}$ \\
$\mathrm{m}_{1}$ & 19,87 & 36,13 & $49,10^{\mathrm{a}}$ \\
\hline
\end{tabular}

Keterangan : Angka-angka yang diikuti huruf yang sama menunjukkan tidak berbeda nyata berdasarkan uji BNT pada taraf $\alpha=5 \%$

Hasil sidik ragam menunjukan bahwa perlakuan mulsa jerami tidak berpengaruh nyata terhadap tinggi tanaman kedelai umur 15 dan 30 HST, jumlah polong isi per tanaman, jumlah polong hampa per tanaman, berat 100 biji per tanaman dan produksi kedelai per petak namun berpengaruh nyata terhadap tinggi tanaman kedelai umur 45 HST. Perlakuan mulsa jerami tidak berpengaruh nyata terhadap tinggi tanaman kedelai umur 15 dan 30 HST, jumlah polong isi per tanaman, jumlah polong hampa per tanaman, berat 100 biji per tanaman dan produksi kedelai per petak diduga karena jerami yang digunakan sebagai mulsa belum terurai dengan sempurna menjadi bahan anorganik yang dapat dimanfaatkan tanaman sebagai unsur hara yang tersedia.. Menurut Harjadi (1993), banyaknya bahan organik yang terdekomposisi akan mempengaruhi jumlah unsur-unsur mineral yang diperlukan untuk pertumbuhan tanaman. Kemudian diperjelas oleh Lingga (1991) yang menyatakan bahwa suatu tanaman akan tumbuh subur bila elemen yang tersedia cukup dan sesuai dengan kebutuhan tanaman. Demikian pula pendapat Islami dan Utomo (1995), agar tanaman dapat tumbuh dengan baik diperlukan unsur hara dan air yang cukup dan seimbang. Perlakuan mulsa jerami berpengaruh nyata terhadap tinggi tanaman kedelai umur 45 HST. Perlakuan mulsa yang terbaik pada tinggi tanaman kedelai umur $45 \mathrm{HST}$ adalah perlakuan $\mathrm{m}_{1}$ (dengan mulsa jerami) dimana rata - rata tinggi tanaman mencapai $49,10 \mathrm{~cm}$. Hal ini diduga karena kedelai menyukai tempat yang berhawa panas atau kering asalkan kelembapan tanah masih cukup terjamin. Pada saat pengamatan berdasarkan data curah hujan menunjukkan bahwa saat pengamatan intensitas curah hujan rendah karena terjadinya hujan ( terdapat 42 hari hujan dalam 153 hari pengamatan) tidak merata dalam sebulan sehingga berpengaruh terhadap kelembapan tanah yang cenderung akan semakin rendah sehingga pada umur 45 HST terjadi perbedaan kelembapan tanah dimana pada perlakuan $\mathrm{m}_{1}$ (dengan mulsa jerami) keadaan kelembapan tanah masih cukup terjamin sehingga pertumbuhannya menjadi lebih baik. Hal ini sesuai dengan pendapat Suprapto (1998) yang menyatakan bahwa tempat yang berhawa panas atau kering disukai oleh tanaman kedelai dibandingan dengan iklim yang sangat lembab. Pertumbuhan yang optimal dapat diperoleh 
dengan menanam kedelai pada bulan - bulan

terjamin.

kering asalkan kelembapan tanah masih cukup

\section{Pengaruh Perlakuan Sistem Tumpangsari Terhadap Pertumbuhan dan Produksi Tanaman Tumpangsari Jagung Manis dan Kedelai}

\section{Pertumbuhan dan produksi tanaman Jagung Manis}

Tabel 3. Rata-Rata Tinggi Tanaman Jagung pada Perlakuan Tumpang Sari

\begin{tabular}{cccc}
\hline Perlakuan & \multicolumn{3}{c}{ Rata-rata tinggi tanaman jagung (cm) } \\
\cline { 2 - 4 } Tumpang Sari & 15 HST & 30 HST & 45 HST \\
\hline $\mathrm{p}_{2}$ & $24,21^{\mathrm{a}}$ & $89,57^{\mathrm{a}}$ & 145,00 \\
$\mathrm{p}_{3}$ & $20,81^{\mathrm{b}}$ & $70,07^{\mathrm{b}}$ & 130,46 \\
$\mathrm{p}_{4}$ & $25,59^{\mathrm{a}}$ & $89,37^{\mathrm{a}}$ & 128,99 \\
$\mathrm{p}_{5}$ & $22,65^{\mathrm{ab}}$ & $82,71^{\mathrm{a}}$ & 122,95 \\
\hline
\end{tabular}

Keterangan : Angka-angka yang diikuti huruf yang sama menunjukkan tidak berbeda nyata berdasarkan uji BNT pada taraf $\alpha=5 \%$

Tabel 4. Rata-Rata Diameter tongkol tanpa kelobot pada Perlakuan Tumpang Sari

Perlakuan
Tumpang Sari
Diameter tongkol tanpa kelobot $(\mathrm{cm})$

\begin{tabular}{lc}
\hline $\mathrm{p}_{1}$ & $14,90^{\mathrm{a}}$ \\
$\mathrm{p}_{3}$ & $12,66^{\mathrm{c}}$ \\
$\mathrm{p}_{4}$ & $14,11^{\mathrm{ab}}$ \\
$\mathrm{p}_{5}$ & $12,94^{\mathrm{bc}}$ \\
\hline
\end{tabular}

Keterangan : Angka-angka yang diikuti huruf yang sama menunjukkan tidak berbeda nyata berdasarkan uji BNT pada taraf $\alpha=5 \%$

Tabel 5. Rata-Rata Produksi jagung per petak pada Perlakuan Tumpang Sari

\begin{tabular}{cc}
\hline Perlakuan & Produksi jagung per petak $(\mathrm{kg})$ \\
Tumpang Sari & $4,15^{\mathrm{ab}}$ \\
$\mathrm{p}_{1}$ & $2,09^{\mathrm{c}}$ \\
$\mathrm{p}_{3}$ & $4,28^{\mathrm{a}}$ \\
$\mathrm{p}_{4}$ & $3,18^{\mathrm{b}}$ \\
$\mathrm{p}_{5}$ & \\
\hline
\end{tabular}

Keterangan : Angka-angka yang diikuti huruf yang sama menunjukkan tidak berbeda nyata berdasarkan uji BNT pada taraf $\alpha=5 \%$

Hasil sidik ragam menunjukan bahwa perlakuan sistem tumpangsari tidak berpengaruh nyata terhadap tinggi tanaman jagung umur 45 HST, umur saat berbunga jantan $80 \%$ dan panjang tongkol namun berpengaruh nyata terhadap tinggi tanaman jagung umur 15 dan 30 HST, diameter tongkol tanpa kelobot serta berpengaruh sangat nyata terhadap produksi jagung per petak Perlakuan sistem tumpangsari berpengaruh nyata terhadap tinggi tanaman jagung pada umur 15 dan 30 HST dimana perlakuan sistem tumpangsari terbaik pada perlakuan $\mathrm{p}_{2}$ (jagung manis monokultur) dan $\mathrm{p}_{4}$ (tumpang sari 3 baris jagung di antara tanaman kedelai) dimana rata-rata tinggi tanaman jagung perlakuan $\mathrm{p}_{2}$ berturut - turut adalah $24,21 \mathrm{~cm}$ (15 HST) dan 89,57 cm (30 HST) sedangkan perlakuan $\mathrm{p}_{4}$ berturut - turut adalah $25,59 \mathrm{~cm}(15$ HST) dan $89,37 \mathrm{~cm}$ (30 HST). Hal ini diduga karena pengaruh jarak tanam yang rapat karena populasi tanaman jagung yang lebih padat pada kedua perlakuan tersebut dibandingkan dengan perlakuan yang lain yaitu perlakuan $\mathrm{p}_{3}$ (tumpang sari kedelai + jagung dibarisan tengah) dan $\mathrm{p}_{5}$ (tumpang sari 2 baris jagung disamping kiri dan kanan tanaman kedelai) sehingga terjadi persaingan untuk memperoleh sinar matahari yang dibutuhkan tanaman untuk proses fotosintesa.

Pada umur 45 HST perlakuan sistem tumpangsari tidak berpengaruh nyata terhadap tinggi tanaman jagung. Hal ini diduga karena pertumbuhan tinggi tanaman jagung sudah mencapai mendekati tinggi yang optimal maka proses selanjutnya untuk pembentukan buah jagung sebagai cadangan makanannya sehingga tidak berbeda nyata yang ditunjukkan dengan perlakuan sistem tumpangsari tidak berpengaruh nyata terhadap tinggi tanaman jagung umur 45 
HST. Hal ini sesuai dengan pendapat Jumin (1991) yang menyatakan bahwa kerapatan tanaman mempunyai hubungan yang tidak dapat dipisahkan dengan jumlah hasil yang akan diperoleh dari sebidang tanah karena berpengaruh terhadap populasi tanaman, efisiensi pemanfaatan cahaya dan juga mempengaruhi kompetisi dalam penyerapan air dan unsur hara sehingga akan mempengaruhi hasil.

Perlakuan sistem tumpangsari berpengaruh nyata terhadap diameter tongkol tanpa kelobot pada tanaman jagung. Perlakuan sistem tumpangsari terbaik pada perlakuan $\mathrm{p}_{2}$ untuk parameter diameter tongkol tanpa kelobot yaitu $14,90 \mathrm{~cm}$. Hal ini disebabkan tanaman jagung mempunyai sifat penyerbukan silang sehingga populasi tanaman sangat mempengaruhi proses penyerbukan silang tersebut. Serbuk sari bunga jantan akan diterbangkan oleh angin dan diantaranya jatuh pada tangkai putik dan selanjutnya masuk pada saluran tangkai putik, sampai akhirnya berbentuk biji. Biji jagung tersusun rapi pada tongkol dan berkeping tunggal. Perlakuan $\mathrm{P}_{2}$ yang populasi tanaman jagungnya terbanyak lebih optimal dalam melakukan penyerbukan silang sehingga biji yang terbentuk lebih optimal pula. Hal ini sesuai dengan pendapat Suprapto (1997) yang menyatakan bahwa jagung manis adalah salah satu dari sekian banyak tanaman yang melaksanakan penyerbukan silang. Dimana serbuk sari bunga jantan akan diterbangkan oleh angin dan diantaranya jatuh pada tangkai putik (rambut) dan selanjutnya masuk pada saluran tangkai putik, sampai akhirnya berbentuk biji. Selain itu, karena perlakuan $\mathrm{P}_{2}$ mempunyai lingkungan yang lebih lembab dibandingkan dengan perlakuan yang lainnya karena populasi tanaman jagung yang lebih banyak sehingga mempunyai ketersediaan air yang cukup untuk pertumbuhan dan produksinya sehingga berpengaruh terhadap pengisian buah biji. Hal ini sesuai dengan pendapat Rukmana (1997) yang menyatakan bahwa pertumbuhan dan hasil tanaman jagung, juga dipengaruhi oleh sifat fisik tanah, yaitu tanah harus gembur, airase dan drainase baik dan tanah mengandung cukup air. Oleh karena itu, semakin banyak dan besar biji yang terbentuk maka akan berpengaruh terhadap semakin besar pula diameter tongkol tanpa kelobot tanaman jagung.

Perlakuan sistem tumpangsari berpengaruh sangat nyata terhadap produksi jagung manis per petak. Perlakuan sistem tumpangsari terbaik pada perlakuan $\mathrm{p}_{4}$ dimana rata-rata produksi jagung per petak adalah 4,28 kg / petak. Hal ini disebabkan populasi yang banyak sehingga ketersediaan air dan kelembapannya terjaga untuk pertumbuhan dan produksi yang berpengaruh pada pengisian biji, oleh karena itu maka berat buah per petak juga semakin besar. Diperjelas oleh Harjadi (1993), jarak tanam mempengaruhi populasi tanaman dan efisiensi penggunaan air dan zat hara, dengan demikian akan mempengaruhi hasil.

Berdasarkan uraian tersebut dapat diketahui bahwa perlakuan sistem tumpangsari berpengaruh sangat nyata terhadap produksi jagung manis per petak berdasarkan pengaruh populasi yang akan mempengaruhi hasil. Hal ini ditunjukkan oleh parameter produksi jagung per petak dimana perlakuan $\mathrm{p}_{4}$ yang terbaik.

Perlakuan sistem tumpangsari tidak berpengaruh nyata terhadap umur saat berbunga jantan $80 \%$ pada tanaman jagung. Hal ini disebabkan perlakuan sistem tumpangsari tidak mempengaruhi fase generatif tetapi parameter umur saat berbunga jantan $80 \%$ dipengaruhi oleh faktor lingkungan terutama intensitas cahaya dan suhu serta sifat tanaman itu sendiri. Hal ini sesuai dengan pendapat Daryanto dan Satifah (1992) yang menyatakan bahwa masa peralihan dari fase vegetatif ke fase generatif seperti proses pembungaan ditentukan oleh sifat tanaman itu sendiri. Perlakuan sistem tumpangsari tidak berpengaruh nyata terhadap panjang tongkol tanaman jagung. Hal ini disebabkan faktor sifat tanaman itu sendiri sehingga ukuran panjang tongkol tanaman jagung relatif seragam. Hal ini sesuai dengan pendapat Tanindo Subur Prima (2003) yang menyatakan bahwa panjang tongkol jagung manis bisi $\pm 20 \mathrm{~cm}$.

\section{Pertumbuhan dan produksi tanaman Kedelai}

Tabel 3. Rata-Rata Produksi Per Petak pada Perlakuan Tumpang Sari

\begin{tabular}{cc}
\hline Perlakuan & Rata-rata produksi per petak $(\mathrm{kg})$ \\
\hline Tumpang Sari & $2,55^{\mathrm{a}}$ \\
$\mathrm{P}_{1}$ & $2,43^{\mathrm{b}}$ \\
$\mathrm{P}_{3}$ & $2,17^{\mathrm{d}}$ \\
$\mathrm{P}_{4}$ & $2,36^{\mathrm{c}}$ \\
$\mathrm{P}_{5}$ & \\
\hline
\end{tabular}

Keterangan : Angka-angka yang diikuti huruf yang sama menunjukkan tidak berbeda nyata berdasarkan uji BNT pada taraf $\alpha=5 \%$ 
Hasil sidik ragam menunjukan bahwa perlakuan sistem tumpangsari tidak berpengaruh nyata terhadap tinggi tanaman kedelai umur 15 , 30 dan 45 HST, jumlah polong isi per tanaman, jumlah polong hampa per tanaman, berat 100 biji per tanaman namun berpengaruh sangat nyata terhadap produksi kedelai per petak. Perlakuan sistem tumpangsari tidak berpengaruh nyata terhadap tinggi tanaman kedelai. Hal ini diduga karena kelembapan tanah untuk semua perlakuan sistem tumpangsari cukup terjamin. Hal ini sesuai dengan pendapat Suprapto (1998) yang menyatakan bahwa pertumbuhan yang optimal dapat diperoleh dengan menanam kedelai pada bulan - bulan kering asalkan kelembapan tanah masih cukup terjamin. Perlakuan sistem tumpangsari tidak berpengaruh nyata terhadap jumlah polong isi per tanaman kedelai. Hal ini disebabkan faktor tanah yang kurang subur dimana kandungan $\mathrm{N}, \mathrm{P}$ dan $\mathrm{K}$ termasuk rendah menurut Hardjowigeno (1992) berdasarkan hasil analisa kimia dan tekstur tanah di lahan pengamatan dimana kandungan unsur $\mathrm{N}$ hanya sebesar $0,22 \%$ dan unsur $\mathrm{P}$ hanya 7,0 ppm serta unsur $\mathrm{K}$ hanya $14,9 \mathrm{ppm}$. Berdasarkan uraian tersebut dapat diketahui bahwa sistem tumpangsari tidak dapat menyerap unsur hara secara optimal karena unsur hara yang tersedia tidak mencukupi untuk produksi tanaman kedelai yang ditunjukkan oleh parameter jumlah polong isi per tanaman. Perlakuan sistem tumpangsari tidak berpengaruh nyata terhadap jumlah polong hampa per tanaman kedelai. Hal ini disebabkan faktor tanah yang kurang subur. Menurut Sarief (1986), kesuburan tanah merupakan faktor terpenting untuk menghasilkan produksi pertanian yang optimal tanpa mengurangi tingkat kesuburan tanahnya. Ketersedian unsur hara yang dapat diserap oleh tanaman merupakan faktor untuk mempengaruhi tingkat produksi tanaman. Dari hasil analisa kimia dan tekstur tanah di lahan pengamatan dimana kandungan unsur $\mathrm{N}$ hanya sebesar $0,22 \%$ dan unsur $\mathrm{P}$ hanya 7,0 ppm serta unsur K hanya 14,9 ppm berdasarkan status kesuburan tanah menurut Hardjowigeno (1992)

\section{Pengaruh Kombinasi Perlakuan Mulsa Jerami dengan Sistem Tumpangsari}

Hasil sidik ragam terhadap kombinasi perlakuan mulsa jerami dengan sistem tumpangsari tidak berpengaruh nyata terhadap pertumbuhan dan produksi tanaman tumpangsari jagung manis dan kedelai, hasil tersebut ditunjukkan oleh parameter tinggi tanaman jagung dan kedelai umur 15, 30 dan 45 HST, umur saat berbunga jantan $80 \%$ tanaman jagung, panjang tongkol jagung, diameter tongkol tanapa kelobot, produksi jagung per petak, jumlah polong isi per tanaman kedelai, jumlah polong hampa per pada, kandungan $\mathrm{N}, \mathrm{P}$ dan $\mathrm{K}$ tanah di lahan tersebut termasuk rendah. Rendahnya kandungan unsur hara tersebut menyebabkan sistem tumpang sari tidak dapat memanfaatkan unsur hara yang tersedia karena kurang mencukupi untuk memenuhi kebutuhan unsur hara bagi produksi tanaman

Perlakuan sistem tumpangsari tidak berpengaruh nyata terhadap berat 100 biji per tanaman kedelai. Menurut Lingga (1991) yang menyatakan bahwa suatu tanaman akan tumbuh subur bila elemen yang tersedia cukup dan sesuai dengan kebutuhan tanaman. Dari hasil analisa kimia dan tekstur tanah di lahan pengamatan dimana kandungan unsur $\mathrm{N}$ hanya sebesar $0,22 \%$ dan unsur $\mathrm{P}$ hanya $7,0 \mathrm{ppm}$ serta unsur $\mathrm{K}$ hanya 14,9 ppm berdasarkan status kesuburan tanah menurut Hardjowigeno (1992) pada Lampiran 21, kandungan $\mathrm{N}, \mathrm{P}$ dan $\mathrm{K}$ tanah di lahan tersebut termasuk rendah. Rendahnya kandungan unsur hara tersebut menyebabkan sistem tumpang sari tidak dapat memanfaatkan unsur hara yang tersedia karena kurang mencukupi untuk memenuhi kebutuhan unsur hara bagi produksi tanaman.

Perlakuan sistem tumpangsari berpengaruh nyata terhadap produksi kedelai per petak. Perlakuan sistem tumpangsari terbaik pada perlakuan $\mathrm{P}_{1}$ adalah $2,55 \mathrm{~kg} /$ petak sedangkan rata-rata produksi kedelai per petak terendah dicapai pada $\mathrm{P}_{4}$ adalah $2,17 \mathrm{~kg} /$ petak. Hal ini disebabkan populasi yang rapat maka berat buah per petak juga semakin besar. Diperjelas oleh Harjadi (1993), jarak tanam mempengaruhi populasi tanaman dan efisiensi penggunaan air dan zat hara, dengan demikian akan mempengaruhi hasil. Berdasarkan uraian tersebut dapat diketahui bahwa perlakuan sistem tumpangsari berpengaruh sangat nyata terhadap produksi kedelai per petak berdasarkan pengaruh populasi yang akan mempengaruhi hasil. Hal ini ditunjukkan oleh parameter produksi kedelai per petak dimana perlakuan $\mathrm{P}_{1}$ menjadi perlakuan yang terbaik berdasarkan produksi kedelai per petak.

tanaman kedelai, berat 100 biji per tanaman kedelai serta produksi kedelai per petak. Tidak adanya pengaruh nyata tersebut diduga kedua faktor perlakuan tersebut mempunyai peran yang tidak saling mendukung dalam hal pertumbuhan maupun produksi tanaman jagung manis dan kedelai. Adapun peranan mulsa jerami dapat menekan laju pertumbuhan gulma, menurunkan suhu tanah dan sebagai penutup permukaan tanah untuk mengurangi penguapan air dari tanah. Sedangkan sistem tumpangsari sendiri sebagai 
bentuk yang memberikan produksi tinggi karena penggunaan tanah dan sinar matahari lebih efisien, apabila terjadi serangan hama dapat terhindar dari kegagalan panen karena jenis tanaman jagung manis dan kedelai berbeda.

\section{KESIMPULAN}

1. Perlakuan mulsa jerami tidak berperan (tidak berpengaruh nyata) terhadap pertumbuhan dan produksi tanaman jagung manis dan tanaman kedelai yang ditanam secara tumpangsari.

2. Perlakuan sistem tumpangsari berpengaruh nyata terhadap tinggi tanaman jagung pada umur 15 dan 30 HST, diameter tongkol jagung

\section{DAFTAR PUSTAKA}

AAK.1988. Petunjuk Praktis Bertanam Sayuran. Kanisius, Yogyakarta. $122 \mathrm{hlm}$.

BPTP Kaltim, 1999. Analisis Data Pokok untuk Pembangunan Wilayah Provinsi Kaltim, BPTP Prov. Dati I Kaltim, Samarinda.

Daryanto dan Satifah, 1992. Pengetahuan Dasar Biologi Bunga dan Teknik Penyerbukan Silang Buatan, Gramedia, Jakarta.

Dispertan Kaltim, 1998. Laporan Tahunan. Dinas Pertanian Tanaman Pangan Tingkat I Kalimantan Timur, Samarinda.

Dispertan Kaltim, 2000. Laporan Tanaman Dinas Pertanian Tanaman Pangan Propinsi Dati Kalimantan Timur Tahun 1999. Dinas Pertanian Tanaman Pangan Kalimantan Timur, Samarinda.

Hardjowigeno, 1992. Ilmu Tanah, Mediyatama Sarana Perkasa, Jakarta.

Islami T. dan Utomo, 1995. Hubungan Tanah, Air dan Tanaman, IKIP Semarang Press, Semarang.

Jumin, H.B, 1991. Dasar- Dasar Agronomi, Rajawali Press, Jakarta.

Lingga, 1991. Petunjuk Penggunaan Pupuk, Penebar Swadaya, Jakarta.
Sesuai dengan pendapat Steel dan Torrie (1993), bahwa apabila dua faktor tidak berbeda nyata maka disimpulkan faktor tersebut bertindak bebas satu dengan lainnya.

tanpa kelobot, produksi jagung per petak serta produksi kedelai per petak.

3. Kombinasi perlakuan mulsa jerami dengan sistem tumpangsari tidak berpengaruh nyata karena masing-masing faktor memberikan faktor terpisah terhadap pertumbuhan dan produksi tanaman tumpangsari jagung manis dan kedelai.

PSK Sekolah Pertanian Kaltim, 1997. Budidaya Tanaman Pangan. Paket Satuan Keterampilan (PSK), Sekolah Pertanian Dinas Pertanian Tingkat I Prop. Kalimantan Timur, Samarinda.

Rismunandar.1983. Bertanam Kedelai. Terate, Bandung. $52 \mathrm{hlm}$.

Rukmana, R.1997. Kedelai Budidaya dan Pasca Panen. Kanisius, Yogyakarta.92 hlm.

Sarief ES, 1986. Kesuburan dan Pemupukan Tanah Pertanian, Pustaka Buana, Bandung.

Steel, R.GD. dan Torrie, J.H, 1993. Prinsip dan Prosedur Statistika, Alihbahasa ; Bambang Sumantri, Gramedia Pustaka Utama, Jakarta.

Suprapto, 1997. Bercocok Tanam Jagung. Penebar swadaya, Jakarta.

Suprapto, H. S. 1998. Bertanam Kedelai. Penebar swadaya, Jakarta. $74 \mathrm{hlm}$.

Sutedjo, MM dan A.G Kartaspoetra, 1988. Pupuk dan Cara Pemupukan. Bina Aksara, Jakarta. 177 hlm.

Tanindo Subur Prima, 2003. Katalog Cap Kapal Terbang 2003 - 2005, Tanindo Subur Prima, Sidoarjo.

Utami, K.P. 1998. Prospek Cerah Bertanam Kedelai. Trubus 29 (339) : $80-81$. 